\title{
A ATUalidade da discussão sobre a INDÚSTRIA Cultural em Theodor W. Adorno
}

\author{
Jean Henrique Costa
}

\begin{abstract}
RESUMO: Este ensaio vem problematizar acerca da atualidade do conceito de indústria cultural (Kulturindustrie), no projeto da teoria crítica de Theodor W. Adorno, objetivando mostrar que as atuais limitaçóes impostas ao debate derivam mais do fundamento não-dialético dos que apontam sua restrição do que da própria potência da teorizaçấo frankfurtiana.
\end{abstract}

PALAVRAS-CHAVE: Teoria Crítica. Indústria Cultural. Theodor W. Adorno. Max Horkheimer.

A expressão Indústria Cultural (Kulturindustrie) foi cunhada pela primeira vez em 1947, por Theodor W. Adorno e Max Horkheimer, nos fragmentos filosóficos reunidos sob o título de Dialética do Esclarecimento, termo que viria contrapor o conceito cultura de massa, por tratar de um fenômeno distinto quanto a sua natureza. Preferiram, então, “[...] usar a expressão 'indústria cultural', para evitar a confusão com uma arte que surgisse espontaneamente no meio popular, que é algo bastante diferente" (FREITAS, 2008, p. 17). Na apreciação de Wolfgang Leo Maar (2003), o termo "cultura de massas" parece indicar uma cultura solicitada pelas próprias massas, fora do alcance da totalização. Contrariamente, o termo "indústria cultural" ressalta o mecanismo pelo qual a sociedade como um todo é construída, sob o escudo do capital, reforçando as condiçóes vigentes. Segundo Gabriel Cohn, trata-se de um conceito elaborado como resposta direta ao conceito de cultura de massa. Ambos compartilham a referência à cultura. "Mas é significativo que, enquanto na expressão 'cultura de massa' ela aparece como nome, na sua contrapartida crítica ela esteja na condição de predicado” (COHN, 1998, p. 18).

Em 1962, Adorno (1971, p. 287) chega a afirmar que, ao que tudo indica, "[...] o termo indústria cultural foi empregado pela primeira vez no

\footnotetext{
${ }^{1}$ Professor da Universidade do Estado do Rio Grande do Norte - UERN. Doutor em Ciências Sociais (PGCS/UFRN). E-mails: jeanhenrique@uern.br; jeanhenriquecosta@hotmail.com
} 
livro Dialektik der Aufklärung, que Horkheimer e eu publicamos em 1947, em Amsterdā". Tal oposição conceitual se deveu ao fato da cultura de massa remontar a uma cultura espontaneamente surgida da própria massa, da forma contemporânea chamada de arte popular. Todavia, algo efetivamente distinto ocorre com a indústria cultural.

O que importa destacar é que dessa arte popular a indústria cultural se distingue radicalmente: enquanto a cultura popular teria um caráter mais espontâneo e nasceria internamente, numa dada comunidade, a indústria cultural constitui uma manifestação maquinal produzida exteriormente (sob a égide do capital).

A indústria cultural é fruto da oportunidade de expansão da lógica do capitalismo sobre a cultura. Náo somente esse avanço progressivamente acontece no domínio do cultural, mas também, cada vez mais, nas esferas da biologia (corpo), da natureza, das relaçóes humanas, do conhecimento etc. Como enfatizou Ernest Mandel, existe no capitalismo tardio uma tendência à industrialização das atividades superestruturais, e muitas dessas atividades já se organizam hoje em termos industriais, produzidas para o mercado e para a maximização do lucro: "[...] a pop-arte, os filmes feitos para a televisão e a indústria do disco são fenômenos típicos da cultura capitalista tardia” (MANDEL, 1985, p. 352). Daí que, para Hullot-Kentor (2008, p. 21), o conceito de indústria cultural em Adorno "[...] nos leva a crer que foi para ele um achado preciso, resultado de uma auscultação minuciosa das tendências históricas, mais do que um neologismo historicamente oportuno".

Há, contudo, quem ateste hoje em dia as limitaçóes do conceito e, inegavelmente, a realidade atual é bem distinta daquela vigente no período vital de Theodor Adorno e Max Horkheimer. Todavia, suas limitaçóes não invalidam, nem o fenômeno, nem tampouco o método crítico. A indústria cultural está aí! Todos os dias, seus produtos, dentre best-sellers, games, Cds e Dvds, invadem o cotidiano de bilhôes de pessoas. O que dizer, então, dessas cifras?

Sumariando, com Costa (2001, p. 110), a heteronomia cultural; a transformação da arte em mercadoria; a hierarquização das qualidades; a incorporação de novos suportes de comunicação pelos setores que já detinham os meios de reprodução simbólica; o caráter de montagem dos produtos; a capacidade destes em prescrever a reação dos receptores; a reprodução técnica comprometendo a autenticidade da arte; o consumidor passivo; a falsa identidade entre o universal e o particular; a técnica como ideologia; 
o "novo" como manifesto do imediato; e a fraqueza do "eu" apontam para a continuidade da administração da cultura. Dessa forma, o conceito não é apenas atual, como empiricamente demonstrável. Segundo afirma Crochík (2008, p. 304), “[...] certamente Adorno escreveu em outro tempo e em outros lugares, mas a regressão individual como fruto do avanço da sociedade da administração prossegue". O capitalismo continua a liquidar, não com o trabalho, mas com o trabalhador, e, para além disso, a criação de necessidades supérfluas vem se ampliando.

Logo, parte importante das limitaçóes impostas ao debate deriva mais do fundamento não-dialético dos que apontam sua restrição do que da própria energia da teorização. Os críticos - precariamente críticos! - suprimem a dialética em Adorno e, ingenuamente, acreditam estar o autor superado.

Uma vez que ela [a crítica cultural] retira o espírito da dialética que este mantém com as condiçôes materiais, passa a concebê-lo unívoca e linearmente como um princípio de fatalidade, sonegando assim os momentos de resistência do espírito. (ADORNO, 2001, p. 13).

Certamente o grande entrave do conceito de indústria cultural, no âmbito das ciências sociais, deva-se à não mensurabilidade dos efeitos advindos dessa produção cultural de massa. Adorno reconhece essa impossibilidade. Para ele, com razão, "[...] não é possível estabelecer com clareza um nexo causal, por exemplo, entre as 'repercussóes' das músicas de sucesso e seus efeitos psicológicos sobre os ouvintes" (ADORNO, 1991, p. 93). Apesar desse impasse entre a especulação filosófica e a verificação empírica, a contenda acerca do problema em tese não invalida sua autoridade, nem tampouco suas propriedades relacionais.

Algumas teorias sociais hoje, embora reconheçam o peso de determinados arranjos sociais para a explicação sociológica, apregoam certa reflexividade do sujeito no direcionamento de suas vidas, baseando-se, ora no avanço dos processos de racionalização e secularização, ora em perspectivas fenomenológicas (mundos vividos). Algumas teorias derivam mais da ênfase do papel do indivíduo na vida social; outras destacam mais a própria sociedade como estrutura coercitiva, que pré-existe ao indivíduo. Individualismos metodológicos afirmam, em certo sentido, que o conceito de indústria cultural possui forte dimensáo determinista, pois coloca o indivíduo como ente muito passivo frente as suas escolhas. Ora, tais posições são parciais, uma vez que 
não há determinismo no conceito de indústria cultural. Não há simplesmente imposição de cima para baixo. Estrategicamente, a indústria cultural lança no mercado coisas que são representaçôes dos próprios consumidores, criadas antes por prescrição e fortalecidas pelo cerco sistemático de sua exposição ${ }^{2}$. O próprio Adorno reconhece que os consumidores não são estúpidos. A indústria cultural sempre conta com um pouco de bom senso por parte de seus consumidores (FREITAS, 2005).

A aceitação sem resistência - ou com pouca - não deriva simplesmente das necessidades intrínsecas ao indivíduo, já que seria uma explicação muito banal. Prescreve-se, logicamente, o que conjunturalmente permite ser prescrito. Todavia, não se cria o produto e se joga para o consumidor. Pelo contrário, estuda-se o consumidor e se lança a mercadoria (sugerem-se necessidades). Náo há puramente uma questáo de autonomia, mas um jogo entre quem sabe as regras e quem não as conhece (ou não quer conhecer). "A verdade em tudo isso é que o poder da indústria cultural provém de sua identificação com a necessidade produzida” (ADORNO; HORKHEIMER, 1985, p. 113).

Adorno e Horkheimer (1985), na Dialética do Esclarecimento, abrem o problema da indústria cultural, afirmando que o declínio da religião no mundo ocidental, decorrente do avanço dos processos de racionalização e secularização (reflexão weberiana por excelência), não causou um caos cultural pela falta de uma unidade de referência coletiva, pois o cinema, o rádio e as revistas se constituíram num substituto para ela. Com o avanço da produção e do uso desses sucedâneos, o núcleo essencial da discussão reside em torno da problematização acerca da indústria cultural e seu caráter mistificador (fetichista) da realidade e coisificador ${ }^{3}$ do homem.

Adorno e Horkheimer constatam que o cinema e o rádio, por exemplo, não precisam mais se camuflar de arte, uma vez que o caráter de mercadoria já está estampado em cada um deles. Música, cinema, literatura magazine etc., tudo está a serviço do mercado. "A verdade de que não passam de um negócio, eles a utilizam como uma ideologia destinada a legitimar o lixo que propositalmente produzem" (ADORNO; HORKHEIMER, 1985, p. 100).

\footnotetext{
2 "Pela via do fetichismo da mercadoria, o modo de produção impóe formas determinadas que, como 'consciência' sujeitada, reproduzem a sujeição ao mesmo tempo em que geram experiências substitutivas pelas quais aparentam se constituir como sujeitos livres” (MAAR, 2002, p. 100).

3 "Em Marx por razôes diversas, as mercadorias passam a ser ativas e o indivíduo se isola e se fragmenta pela divisão social do trabalho", transformando o homem em estatuto de coisa (MATOS, 2005, p. 18). Eric Fromm (1965, p. 82) também partilha desse argumento, uma vez que "[...] o homem transformou a si mesmo numa mercadoria, e sente sua vida como um capital a ser investido com lucro".
} 
Para eles, o novo não é a atitude comercial da obra de arte, mas o fato de hoje serem, de fato, indústrias como tal, renegando a própria ideia de arte.

Um primeiro norte metodológico deve ser colocado, neste momento, em termos de orientação teórica. Segundo Durão (2008, p. 39), “[...] uma das armadilhas mais traiçoeiras no estudo contemporâneo da indústria cultural está na facilidade de adotar uma postura moralizante" diante do assunto, na tendência a lamentar acerca da qualidade dos produtos culturais ofertados. Opondo-se a essa visão, deve-se lembrar que o que determina o funcionamento da indústria cultural a princípio não possui ligação direta com o termo "qualidade", mas com a acumulação de capital. Não se trata em si de considerar a dimensão qualitativa, porém, essencialmente a sua extensão quantitativa. O que puder se transformado em venda, será, pois, objeto da indústria cultural: do funk carioca à massificação dos $C d s$ de Beethoven. Até mesmo a morte, isto é, a exposição de situaçôes-limite, torna-se objeto de venda, conforme problematização de Zuin (2008), ao refletir sobre o projeto do filme holandês Necrocam ${ }^{4}$.

Faz-se mister apontar uma segunda orientação teórica: a crítica à mercantilização da cultura não deve ser feita do ponto de vista da "inferioridade cultural”. Contra tal postura moralizante, deve-se dar um enfoque dialético aos fenômenos. A dialética adorniana é uma dialética negativa (conforme sua obra-prima de 1966), que, afirmando e negando Hegel, consegue dar primazia ao momento de negatividade da análise. Segundo Zuin, Pucci e Ramosde-Oliveira (2001, p. 76-77), a dialética tradicional significa elementos contraditórios que se negam num dos momentos do processo lógico, mas que se compóem, no momento posterior. Há, portanto, a ideia de conciliação de contrários. Utiliza-se do elemento negativo a serviço de um resultado positivo. Em Adorno, há uma proeminente diferença. Segundo afirma, mais especificamente no prefácio da Dialética Negativa, deve-se "[...] libertar a dialética de tal natureza afirmativa, sem perder nada em determinação" (ADORNO, 2009, p. 07). Adorno dará um peso maior ao elemento negativo. Nele, a negatividade é o momento propulsor da dialética, ponto de partida de crítica do princípio da identidade e ponto final como possibilidade de uma nova situação. Trata-se de um método para se pensar e agir sobre a consciência reificada.

\footnotetext{
${ }^{4}$ Prova de que na sociedade atual, até mesmo a morte se metamorfoseia em espetáculo: projeto de um filme em que o cadáver teria uma microcâmera no caixão e, on line, os internautas poderiam controlar, via termostato, o processo de decomposição do corpo (ZUIN, 2008).
} 
Dentre aqueles autores que realizaram uma crítica não-dialética da "trivialidade" dos bens culturais, reconhecidos por Adorno, destaca-se Aldous Huxley. De acordo com Almeida, Adorno e Horkheimer perceberam Huxley como um nome importante no conjunto de pensadores, da primeira metade do século XX, que realizaram uma crítica não-dialética da cultura. Huxley, mesmo tratando o tema sob a ótica da vulgaridade dos bens de massa, trouxe uma distinção muito clara entre "[...] o sentido tradicional da 'cultura' e os avanços, já historicamente visíveis, da 'massa', da 'barbárie', ou mesmo da 'vulgaridade' (como prefere Huxley)” (ALMEIDA, 2008, p. 140).

Adorno (2001, p. 92), no texto Aldous Huxley e a utopia, reconhece que o ponto de partida de Brave New World "[...] parecer ser a percepção da semelhança universal de tudo o que é produzido em massa, sejam coisas ou homens. A metáfora schopenhaueriana da manufatura da natureza é tomada ao pé da letra". Huxley estava atento às modificaçóes no âmbito da cultura, contudo, conforme Almeida (2008), percebeu-as através de simples oposições entre civilização contra barbárie; elite contra massa; prazer real contra prazer administrado; liberdade contra submissão à diversão industrializada. Carece a Huxley, portanto, assumir o caráter histórico, fundamentado pelo modo de produção econômico, dessas oposiçóes. "Elas são, de alguma forma, 'naturalizadas', transformadas em 'destino', sem que haja nenhum modo de reação que não seja o puramente individual [...]” (ALMEIDA, 2008, p. 144). Huxley, então, "[...] fetichiza o fetichismo da mercadoria" (ADORNO, 2001, p. 110), ao separar as relaçóes de produção de seu modo de produção.

Slavoj Žižek (2003) igualmente ressalta a necessidade de não se reduzir algumas perspectivas mais enérgicas a uma mera crítica cultural. Para ele, esse tipo de crítica tem sido feita até mesmo pelos conservadores da sociedade de consumo.

Retomando as implicaçóes do problema, o resultado desse processo de tentativa de fetichizaçáo do mundo, seja da consciência em si, seja do próprio método de análise - não há como esquecer de Agnes Heller (1991) e a sociologia como desfetichização da modernidade ${ }^{5}$-, é a "liquidação" da Ideia de indivíduo. $\mathrm{O}$ conceito de reificação não é só relevante como ampliação do conceito

\footnotetext{
${ }^{5}$ Em Agnes Heller (1991, p. 208), diga-se de passagem, “[...] nâo há sociologia sem uma certa medida de reificação; a metodologia científica inclui a reificação", já que trabalha-se com categorias analíticas que são exteriores aos sujeitos e a investigaçâo. "Adorno, por exemplo, afirmou que as mentes dos sujeitos individuais na sociedade capitalista moderna já tinham sido reificadas e, portanto, o sociólogo empírico incorre numa dupla reificação: a do método de pesquisa e a que decorre da aceitação de sujeitos reificados como fontes de informaçōes verídicas" (HELLER, 1991, p. 210).
} 
de alienação, como concretamente observável na aceitação naturalizada das mercadorias surgidas sob o rótulo de culturais. Reforçando com as palavras de Erich Fromm (1965, p. 85), “[...] os homens são, cada vez mais, autômatos que fazem máquinas que agem como homens e produzem homens que agem como máquinas".

Lucien Goldmann (1980, p. 172) vem afirmar categoricamente que uma das "[...] características fundamentais da sociedade capitalista é a de mascarar as relaçóes sociais entre os homens e as realidades espirituais e psíquicas, dando-lhes o aspecto de atributos naturais das coisas ou de leis naturais". Desse princípio é que emerge a reflexão marxista da reificação, em alemão, Verdinglichung.

\section{Esclarece Tom Bottomore (2001, p. 314):}

Reificação é o ato (ou resultado do ato) de transformação das propriedades, relações e ações humanas em propriedades, relaçóes e açóes de coisas produzidas pelo homem, que se tornaram independentes (e que são imaginadas como originalmente independentes) do homem e governam sua vida. Significa igualmente a transformação dos seres humanos em seres semelhantes a coisas [...] A reificação é um caso 'especial' de alienação, sua forma mais radical e generalizada [...].

Nesse sentido, o clássico ensaio de Georg Lukács - a reificação e a consciência do proletariado - é expressão da maior vitalidade no estudo da dialética marxista e, com ela, o debate sobre a reificação. Para ele, “[...] o homem é confrontado com sua própria atividade, com seu próprio trabalho como algo objetivo, independente dele e que o domina por leis próprias, que lhes são estranhas" (LUKÁCS, 2003, p. 199). Como lembra Max Horkheimer (2007, p. 133), “[...] a máquina expeliu o maquinista; está correndo cegamente no espaço".

Lukács reforça que, assim como o capitalismo se produz e reproduz incessantemente, a reificação penetra na estrutura da consciência humana de maneira cada vez mais profunda. Desse modo, a reificação se amplia com o progresso, substituindo relaçóes originais que antes eram mais transparentes em termos de relaçóes humanas por relaçóes mais parcelizadas e mais fragmentadas. O essencial é reter que a reificação atinge a todos: "Não há uma diferença qualitativa na estrutura da consciência" (LUKÁCS, 2003, p. 219). 
David Harvey (1994, p. 308) também realça esse caráter de ocultação da realidade essencialmente ligado ao avanço da reprodução do capital: "[...] o processo mascara e fetichiza, alcança crescimento mediante a destruição criativa, cria novos desejos e necessidades, explora a capacidade do trabalho e do desejo humanos". Assim, o resultado é a exaustão do indivíduo. Vale lembrar que, em Adorno, a reificação não deve ser simplesmente eliminada, mas pensada como forma determinada. "O real não deve ser eliminado como absoluto, mas negado em sua determinação, superado” (MAAR, 2002, p. 03).

Olgária Matos (2005, p. 50), de tal modo, com base na Teoria Crítica, lembra que o "[...] indivíduo autônomo, consciente de seus fins, está em extinção, em desaparecimento". Domingues (2001, p. 79), da mesma forma, salienta que Adorno e Horkheimer constatam analiticamente pouca importância ao indivíduo na modernidade (devido ao bloqueio estrutural da práxis transformadora): "[...] na verdade, descrevem o que viam como declínio da individualidade”. O pensamento adorniano citado em Habermas é elucidativo: "[...] a experiência individual apóia-se necessariamente no antigo sujeito - historicamente já condenado - 'que ainda é para si, mas não mais em si”" (HABERMAS, 1990, p. 142).

Por conseguinte, nas palavras de Adorno e Horkheimer (1985, p. 128), por um lado, "[...] a individuaçáo jamais chegou a se realizar de fato". Contudo, mesmo assim, a sociedade burguesa, "[...] contra a vontade de seus senhores", transformou os homens de crianças em pessoas, mas à custa de uma individualidade muito indigente e ilusória. Para Freitas (2005), tratase de uma individualidade frustrada diante de si mesma, já que está muito aquém de seus projetos. Precisamente, Zuin (2001, p. 11) enfatiza que “[...] tal debilitação da individualidade é o resultado de um processo social que tem como principal característica a universalização do princípio da lógica da mercadoria, tanto na dimensão objetiva como na subjetiva”. Nesse sentido - e Lukács já alertara para tal fato -, a reificação ocorre tanto na realidade objetiva quanto na subjetiva. Tanto as relaçôes mercantis quanto a consciência se tornam naturalizadas.

A indústria cultural, que não deve ser entendida no sentido estrito da expressão, progrediu graças ao avanço técnico do capitalismo. Segundo Morin (1967, p. 24), “[...] sin el impulso prodigioso del espíritu capitalista, esas invenciones [novas artes técnicas] no hubieran conocido sin duda un desarrollo tan radical y masivamente orientado". Como reforça Adorno, “[...] 
no capitalismo - isso é uma lei essencial - o que existe só pode ser considerado na medida em que se amplia e se expande" (ADORNO, 2008a, p. 122).

Os elementos constitutivos da indústria cultural, ou seja, diversão, entretenimento, prazer etc., já existiam antes mesmo de ela vir à tona. Contudo, o que o século XX viu surgir foi uma imensa maquinaria voltada à comercialização da cultura. Nesse meio, o próprio interior de uma obra artística foi encerrado, quer dizer, a Ideia de autor, o seu caráter de individualidade estética. "A indústria cultural desenvolveu-se com o predomínio que o efeito, a performance tangível e o detalhe técnico alcançaram sobre a obra, que era outrora veículo da Idéia e com essa foi liquidada" (ADORNO; HORKHEIMER, 1985, p. 103-104).

Destarte, os bens da indústria cultural, grosso modo pensando as maiores cifras (racionalizadas, massificadas e padronizadas), são essencialmente mercadorias. Sáo criados para cumprir a função de valor de troca. A racionalidade estética é abandonada em prol da racionalidade instrumental. Donde Zuin (2001, p. 10), sumariamente, afirmar que uma produção cultural submetida "[...] quase que por completo ao seu caráter de valor afasta-se de si própria, ou seja, termina por negar toda possibilidade de felicidade ao dissimular um verdadeiro estado de liberdade".

Padilha (2002) menciona que essa industrialização crescente e suas características mais importantes, na produção de mercadorias, estão também presentes na produção cultural desde o final do século XIX. O cinema e a televisão, por exemplo, obedeceram às mesmas regras da grande indústria: produção em série, divisão racional do trabalho e padronização. Morin (1967, p. 37) ainda realça esse aspecto, ao ressaltar que "[...] el gran arte nuevo, arte industrial tipo, el cine, ha instituido una rigurosa división del trabajo, análoga a la que se opera en una fábrica [...]”. Dessa forma, a cultura produzida pela indústria cultural é padronizada e baseia-se num gosto médio de um público que não tem tempo nem interesse em questionar o que consome. Os meios de comunicação de massa procuram, através de um mundo mágico, naturalizar as regras do jogo social, veiculando códigos serializados para qualquer um em toda a parte do planeta (PADILHA, 2002).

Basicamente em boa parte da produção cultural - da indústria cultural - a qualidade estende-se, antes de qualquer coisa, não por um dado qualitativo - conforme já alertou Durâo (2008) -, mas por cifras de quanto já vendeu e de quanto irá render ainda. "O denominador comum 'cultura' já contém 
virtualmente o levantamento estatístico, a catalogaçãa, a classificação que introduz a cultura no domínio da administraçáo" (ADORNO; HORKHEIMER, 1985, p. 108). As diferenças de qualidade atribuídas aos filmes, livros e músicas têm mais a ver com a sua utilidade de venda do que com sua qualidade intrínseca. Por isso, para que todos possam ser atingidos pela mão invisível da indústria cultural, as próprias distinçôes são criadas, cunhando, assim, um certo ar de opção. "As vantagens e desvantagens que os conhecedores discutem servem apenas para perpetuar a ilusão da concorrência e da possibilidade de escolha" (ADORNO; HORKHEIMER, 1985, p. 101-102).

Esperadamente, como sequelas desse processo, mecanismos diversos da ideologia disseminam que tal produção só existe porque há homens livres e capazes desejando o consumo. O princípio liberal da competência individualista se mostra também eficiente na indústria cultural: tudo pode ser vendido e comprado. No texto Crítica cultural e sociedade, Adorno (2001, p. 21) já se manifestara sumariamente sobre o tema: “[...] hoje 'ideologia' significa sociedade enquanto aparência". Dessa forma, em Adorno a ideologia deixa de ser falsa consciência para se tornar propaganda do mundo: "[...] a organizaçáo do mundo converteu-se a si mesma imediatamente em sua própria ideologia" (ADORNO, 2006, p. 143).

Não há mais ideologia no sentido próprio de falsa consciência, mas somente propaganda a favor do mundo, mediante a sua duplicação e a mentira provocadora, que não pretende ser acreditada, mas que pede o silêncio. (ADORNO, 2001, p. 25).

Por conseguinte, a indústria cultural consegue, no mesmo espaço, obter sucesso de venda em objetos díspares. Pensem, por exemplo, nos programas de auditório, no qual "[...] os 'enternecidos' apresentadores transitam, com espantosa facilidade, entre o relato da filha que foi estuprada pelo próprio pai e os produtos de limpeza do patrocinador" (ZUIN, 2008, p. 55). É como se a tragédia dos outros (alter) fosse coisa pequena frente à miséria individual de cada um (ego).

Nesse sentido, sendo as grandes empresas ligadas ao cinema, à música, às revistas de entretenimento etc. entidades capitalistas que visam ao lucro, não há motivos para desconfiar que seus produtos sejam, quase que literalmente, mercadorias no sentido ríspido do vocábulo. A letra de uma música que é elaborada em um dia, com um instrumental de poucos arranjos, cada um mais 
dispensável que o outro, tematizando a traiçáo de uma esposa e os lamentos do marido melancólico, não é outra coisa senão uma produção industrial, metaforicamente à maneira de uma indústria que produz uma série de canetas esferográficas. Tudo está a serviço da produção de mercadorias ou, mais além, como prefere Durão (2008, p. 43), da superprodução semiótica: “[...] a própria linguagem, sua natureza e forma de operação, quando completamente submetida à lógica de acumulação de capital". Basta que se observe hoje, além dos avanços das tecnologias midiáticas, suas manifestaçôes empíricas: existem filmes em ônibus, insistentes comerciais em camisetas, outdoors humanos etc.; ou seja, há toda uma crescente produção de mensagens a serviço da indústria cultural.

Nesse clima industrial da cultura, cançôes e filmes estandardizados nascem e renascem a cada dia. Às vezes, muda o formato, mas a essência permanece. De todo jeito, é sempre a mesma coisa. De marido traído a temática passa para a mulher submissa; do homem namorador, muda-se para um amor impossível etc. Não apenas músicas de sucesso nascem diariamente, mas também bandas, cantores, astros e novelas "[...] ressurgem ciclicamente como invariantes fixos, mas o conteúdo específico do espetáculo é ele próprio derivado deles e só varia na aparência” (ADORNO; HORKHEIMER, 1985, p. 103). Para Adorno e Horkheimer, cada filme é um trailer do filme seguinte, bem como cada música, seja no conteúdo, seja na montagem do produto.

O público se contenta com a reprodução do que é sempre o mesmo. "Essa mesmice regula também as relaçôes com o que passou. O que é novo na fase da cultura de massas em comparação com a fase do liberalismo avançado é a exclusão do novo. A máquina gira sem sair do lugar” (ADORNO; HORKHEIMER, 1985, p. 111). A indústria cultural consiste, portanto, na repetição do idêntico.

O princípio maior da indústria cultural é a diversão, o entretenimento. Diversão! Palavra tão mencionada pelos apologistas da indústria cultural e tão indigesta (faca de dois gumes). A diversão, nos termos mais genéricos da indústria cultural - diga-se de passagem -, oferece exaustivamente a fuga do cotidiano. Eis o que proporciona a indústria cultural. Fuga! Ernest Mandel esclarece tal proposição:

Para o indivíduo cativo, cuja vida é inteiramente subordinada às leis do mercado - não apenas (como no século XIX) na esfera da produção, mas também na esfera do consumo, da recreação, da cultura, da arte, da educação e das relaçôes pessoais - parece impossível romper a prisão social. A 'experiência cotidiana' reforça e interioriza a ideologia neofatalista da 
natureza da ordem social do capitalismo tardio. Tudo o que resta é o sonho da fuga - por meio do sexo e das drogas, que por sua vez são imediatamente industrializados. (MANDEL, 1985, p. 352).

Logo, "[...] a indústria cultural está corrompida, mas não como uma Babilônia do pecado, e sim como catedral do divertimento de alto nível" (ADORNO; HORKHEIMER, 1985, p. 118). Antecipa-se que o divertimento - protocolarmente - da indústria cultural, em si, não possibilita capacidade de resistência. Tem grande probabilidade de ser mera diversão, distração. Não oferece, em si, possibilidade de emancipação, nem crítica ao status quo. Conforme destacam Adorno e Horkheimer (1985, p. 119), “[...] divertir-se significa estar de acordo [...] É na verdade uma fuga, mas não [...] uma fuga da realidade ruim, mas da última idéia de resistência que essa realidade ainda deixa subsistir".

Para pensar o grande desafio da primeira geração da Teoria Crítica, era preciso ponderar " $[. .$.$] as formas aparentemente mais inofensivas de condução$ da vida no mundo contemporâneo [...], em busca do que nelas possa haver de regressivo" (COHN, 1998, p. 14). Portanto, não há forma aparentemente mais inofensiva do que a ocupação do tempo supostamente livre.

Logo, como resultado de um "divertir" nada afetuoso, termina a grande parte da população envolvida numa forma de dominação muito sutil e, por isso mesmo, mais perigosa. "Assim como o Pato Donald nos cartoons, assim também os desgraçados na vida real recebem a sua sova [surra] para que os espectadores possam se acostumar com a que eles próprios recebem" (ADORNO; HORKHEIMER, 1985, p. 114). O humor triunfa sobre a própria (im)possibilidade de mudança da situaçáo vigente. A arte, como possibilidade de emancipação, de expressão diante do mundo administrado, é abandonada por um humor que nada tem de engraçado, salvo a própria infelicidade de quem ri. A indústria cultural, ofertando cada vez mais seus produtos a um público sempre maior e propiciando diversão sempre "revigorada", oferece algo ao povo e, ao mesmo tempo, priva-o de outra. Oferece diversáo, mas priva-o da possibilidade de uma vida com mais sentido.

Com a indústria cultural, abre-se o sonho capitalista de uma educação plenamente produtivista e consumista. Como sabiamente alertou, já no século XVI, Étienne de La Boétie (2009, p. 48), “[...] o homem é naturalmente livre e quer sê-lo, mas sua natureza é tal que se amolda facilmente à educação que 
recebe". Por isso, não tem sido tarefa abstrusa acomodar os homens segundo os clichês da indústria cultural, pois, como lembra Horkheimer, no reconhecido estudo sobre Autoridade e Família: não é apenas a coação imediata que faz os homens obedecerem a ordens, "[...] mas os próprios homens [que] aprenderam a acatá-las" (HORKHEIMER, 2008, p. 192).

Para Adorno, o clímax dessa situação é atingido quando os esquemas da indústria cultural não permitem mais a evasão ou a dificultam estruturalmente. Segundo aponta, a astrologia representa um dos exemplos mais basilares dessa sujeição. Caso um astrólogo prescreva a um de seus leitores/clientes guiar cuidadosamente seu automóvel, num determinado dia chuvoso, certamente tal conselho não lesará ninguém. Contudo, “[...] prejudicial é a estultice implícita na reivindicação de que esse conselho, válido para qualquer dia e, portanto imbecil, tenha requerido a consulta aos astros" (ADORNO, 1971, p. 294).

Perante a indústria cultural e seus meios de divertimento, pouca coisa (ou quase nada) pode ser considerada inofensiva. $\mathrm{O}$ aforismo $\mathrm{n}^{\mathrm{o}} 5$ de Minima Moralia muito habilmente traz essa reflexão a partir da vida lesada:

Nada mais é inofensivo. As pequenas alegrias, as expressóes da vida que parecem isentas de responsabilidade do pensamento não só contêm um elemento de obstinada tolice, de impassível endurecimento, como se póem imediatamente a serviço do seu extremo oposto. (ADORNO, 2008b, p. 21).

Disso decorre que o cerco da indústria cultural é vigoroso. Não se trata de um conceito-fetiche $e^{6}$, mas de um conceito eminentemente ligado ao seu tempo social, que, em termos de expansão do capitalismo, não se encerrou.

Para Gabriel Cohn (1998), a atualidade do conceito de indústria cultural reside essencialmente em dois aspectos centrais: a ideia de que seus produtos são oferecidos em sistema (o assédio sistemático de tudo para todos) e a noção de que a sua produção obedece prioritariamente a critérios administrativos de controle sobre os efeitos no receptor (capacidade de prescrição de desejos).

Remete à ideia de uma articulaçáo crescente entre todos os ramos de um empreendimento produtor e difusor de mercadorias simbólicas sob o rótulo de cultura, de tal modo que o consumidor se encontre cercado de maneira cada vez mais cerrada por uma rede ideológica com crescente consistência interna [...] O componente crítico básico consiste aqui na ideia de que nos

\footnotetext{
${ }^{6}$ Uma vez que "[...] o desencantamento do conceito é o antídoto da filosofia, ele impede o seu supercrescimento: ele impede que ela se autoabsolutize” (ADORNO, 2009, p. 19).
} 
produtos da indústria cultural os múltiplos níveis não são constituídos por significados intrínsecos aos requisitos formais da construção da obra, mas por níveis de efeitos, ou seja, de relações calculáveis entre determinados estímulos emitidos e as percepçóes ou condutas dos receptores. Náo se trata, aqui, de mera 'manipulação'. Trata-se de uma modalidade específica de entidades simbólicas multidimensionais, produzidas e difundidas segundo critérios prioritariamente (mas não exclusivamente, embora no limite o sejam) administrativos, relativos ao controle sobre os efeitos no receptor e não segundo critérios prioritariamente estéticos, relativos às exigências formais intrínsecas à obra. (COHN, 1998, p. 20-21).

O cerco sobre o indivíduo tem sido crescentemente elevado. Contudo, “[...] com falsa unção a indústria cultural proclama orientar-se pelos consumidores e lhes oferecer aquilo que desejam para si" (ADORNO, 2008b, p. 196). Assim, enquanto ela desaprova toda possibilidade de autonomia do indivíduo, consegue por tabela aprovar muita heteronomia. Da mesma maneira, a capacidade de prescrição sobre o consumidor se constitui em seu grande trunfo. "Não é bem que a indústria cultural se adapte às reaçôes dos clientes, mas sim que elas as finge" (ADORNO, 2008b, p. 197). Por isso, a resistência se torna obstruída mediante tamanhas artimanhas administradas no âmbito da cultura.

Evidentemente, muitas desigualdades hegemônicas da vida social podem não ser estruturadamente criadas pela indústria cultural, mas, aqui e ali, reforçam-se nesse tipo-modelo de consumidor. A indústria cultural "[...] los convierte en lo que ya son, sólo que con mayor intensidad de lo que efectivamente son" (ADORNO, 1969, p. 64).

Não se trata, todavia, de insistir em modelos teóricos pautados essencialmente contra a indústria cultural. Deve-se ter cuidado, pois "[...] o empenho desmistificador é valioso mas não garante a eficácia da desmistificação [e] a ideologia pode estar no excesso como na insuficiência" (KONDER, 2002, p. 258-259).

É mister salientar que, por um lado, conforme realça Konder (2002), não há imunidade contra as ações sutis da ideologia. Ela se manifesta tanto na abstração quanto na empiria; tanto na pretensão à universalidade quanto na resignação à particularidade. Por outro lado, “[...] ao mesmo tempo em que se iludem, os indivíduos inquietos podem questionar suas próprias ilusôes" 
(KONDER, 2002, p. 259). Logo, não se trata de estar a favor, nem contra. A presente discussão não está numa "guerra cultural”".

Algumas análises são essencialmente contra o esboçado na presente reflexão sobre a indústria cultural, alegando sempre elitismo valorativo, excesso de especulação, busca por pureza conceitual e visão de homogeneização onde se verifica diferenciação. No mais, na análise dos meios de comunicação de massa e do consumo popular, de fato, esses elementos são questionáveis, se levados ao extremo. Todavia, é possível efetuar uma análise pujante da indústria cultural, abrindo mão desses quatro equívocos analíticos. E Adorno, na medida do possível, a fez! Primeiramente, se elitismo for analisar criticamente os processos capitalistas e náo se deixar encantar por uma suposta diversidade também capitalistamente $\mathrm{criada}^{8}$, o presente estudo é, sim, elitista. Aliás, em Adorno, há uma crítica da cultura como espírito reservado. Segundo afirma, “[...] ciega es la creencia en una Geiteskultur [cultura do espírito], que, en virtud de su ideal de pureza autosuficiente, renuncia a la efectivización de su contenido y deja librada la realidad al poder y su ceguera" (ADORNO, 1973, p. 102); em segundo lugar, somente uma leitura apressada de Adorno diria que ele vê as massas através da aludida pureza conceitual "perdida". Em Adorno, o capitalismo já se encarregou de transformar tanto Mozart quanto Avióes do Forró em mercadorias; por fim, a indústria cultural no atual estágio de acumulação capitalista não é uma produção de base fordista, mas, de fato, flexível (toyotista). Logo, a diferenciação é sua marca: diferenciação sempre indiferenciada, mas existente.

Assim, evitando suprimir a dialética em Adorno, e também evitando as relaçôes causais e substancialistas, é necessário perpetrar uma tentativa de reequacionamento da relação entre estrutura e ação na análise da indústria cultural, mostrando, para além das ideologias e para além das resistências, uma tensão entre elas. Contudo, a presente reflexão procura evitar um equilíbrio entre os dois lados do campo de forças (dominação e resistência), uma vez que o lado estruturado vem demonstrando uma grande potência em criar e sustentar disposições estéticas. Ou seja, nas palavras de Adorno, há uma desproporção real entre o poder e a impotência social.

\footnotetext{
7 "A expressão 'guerras culturais' sugere batalhas campais entre populistas e elitistas, entre guardiōes do cânone e partidários da différence...” (EAGLETON, 2005, p. 79).

8 “[...] considero esse tâo falado pluralismo como em grande medida ideológico. Ou seja, porque creio que a coexistência das forças é efetivamente capturada e determinada em sua aparência pelo sistema social em que vivemos e tudo domina" (ADORNO, 2008a, p. 130).
} 
La desproporción, que se vuelve desmesurada, entre poder e impotencia sociales se prolonga en el debilitamiento de la composición interna del yo, hasta el punto de que este no se mantiene sin identificarse con lo que, precisamente, lo condena a la impotencia. (ADORNO, 1973, p. 22).

A indústria cultural é atual, vigorosa, e sua força vem desequilibrando insistentemente esse campo. Os indivíduos não são padecentes culturais, mas vivem em estruturas que igualmente não são. $\mathrm{O}$ resultado tem sido a expansão crescente do poder da indústria cultural. Se esse tipo de evidência não for semiformação (Halbbildung), no sentido adorniano, não há o que dizer mais acerca das ideologias como instrumentos de reprodução do status quo, isto é, como esquiva dos "[...] contactos que pudieran sacar a luz algo de su carácter sospechoso” (ADORNO, 1966, p. 196).

Como desfecho, nem tudo é alienação, bem como nem tudo pode ser resumido a uma compreensão de contextos estruturados, na qual a dominação é tomada simplesmente como modo de vida (cultura vivida). A busca de uma síntese epistemológica para essa dualidade - todavia, que não se abstenha de expor o tema da consciência reificada - foi o intento crítico desta reflexão, bem como, igualmente, expor que a indústria cultural contribui decisivamente para a manutenção de certos contextos estruturados de dominação. A potência do conceito adorniano está aí. Só não enxerga aquele que abate a dialética e/ou faz da diversidade cultural uma propaganda do mundo.

COSTA, Jean Henrique. The contemporary relevance of the discussion of the culture industry in Adorno's thought.. Trans/Form/Ação, Marília, v. 36, n. 2, p. 135-154, Maio/ Ago., 2013.

ABSTRACT: This essay discusses the contemporary relevance of the concept of the culture industry (Kulturindustrie) in the critical theory of Theodor W. Adorno, aiming to show that the limitations imposed on present debate derive more from the non-dialectical basis of those who would restrict it than from the strength of Frankfurt School theorizing.

KEYWORDS: Critical theory, Culture industry, Theodor W. Adorno, Max Horkheimer. 


\section{REFERÊNCIAS}

ADORNO, Theodor W. Dialética negativa. Tradução de Marco Antonio Casanova. Rio de Janeiro: Jorge Zahar, 2009.

. Introdução à sociologia. Tradução de Wolfgang Leo Maar. São Paulo: Editora UNESP, 1968/2008a.

. Minima moralia: reflexões a partir da vida lesada. Tradução de Gabriel Cohn. Rio de Janeiro: Beco do Azougue, 2008b.

. Educação e emancipação. Tradução de Wolfgang Leo Maar. 4. ed. Rio de Janeiro: Paz e Terra, 2006.

Prismas: crítica cultural e sociedade. Tradução de Augustin Wernet e Jorge Mattos Brito de Almeida. São Paulo: Ática, 2001.

. O fetichismo na música e a regressão da audição. In: ADORNO, Theodor W; HORKHEIMER, Max. Textos escolbidos. Tradução de Zejko Loparic et alii. 5. ed. São Paulo : Nova Cultural, 1991 (Coleção Os Pensadores, 16).

. Consignas. Traducción de Ramón Bilbao. Buenos Aires: Amorrortu, 1973.

. A indústria cultural. In: COHN, Gabriel. Comunicação e indústria cultural. São Paulo: Nacional; Editora da Universidade de São Paulo, 1971.

. Intervenciones: nueve modelos de crítica. Traducción de Roberto J. Vernengo. Caracas: Monte Ávila, 1969.

. Teoría de la pseudocultura. In: ADORNO, Theodor W; HORKHEIMER, Max. Sociológica. Traducción de Víctor Sánchez de Zavala. Madrid: Taurus, 1966.

; HORKHEIMER, Max. Dialética do esclarecimento: fragmentos filosóficos. Tradução de Guido Antonio de Almeida. Rio de Janeiro: Jorge Zahar, 1985.

ALMEIDA, Jorge. Theodor Adorno, leitor de Aldous Huxley: tempo livre. In: DURĀO, Fábio A.; ZUIN, Antonio; VAZ, Alexandre F. (Org.). A indústria cultural hoje. São Paulo: Boitempo, 2008.

BOTTOMORE, Tom (Org.). Dicionário do pensamento marxista. Tradução de Waltensir Dutra. Rio de Janeiro: Jorge Zahar, 2001.

COHN, Gabriel. A atualidade do conceito de indústria cultural. In: MOREIRA, Adalberto da Silva (Org.). Sociedade global: cultura e religiáo. Petrópolis, RJ: Vozes, 1998.

COSTA, Belarmino César Guimarães da. Barbárie estética e produção jornalística: a atualidade do conceito de indústria cultural. Educação \& Sociedade, ano XXII, no 76, p. 106-120, out. 2001.

CROCHÍK, José Leon. T. W. Adorno e a psicologia social. Psicologia \& Sociedade, 20(2), p. 297-305, 2008.

DOMINGUES, José Maurício. Teorias sociológicas no século XX. Rio de Janeiro: Civilização Brasileira, 2001. 
DURÃO, Fábio A. Da superprodução semiótica: caracterização e implicações estéticas. In: DURÃO, Fábio A.; ZUIN, Antonio; VAZ, Alexandre F. (Org.). A indústria cultural hoje. Sáo Paulo: Boitempo, 2008.

EAGLETON, Terry. A ideia de cultura. Tradução de Sandra Castello Branco. São Paulo: UNESP, 2005.

FREITAS, Verlaine. Adorno e a arte contemporânea. 2. ed. Rio de Janeiro: Jorge Zahar, 2008.

- Indústria cultural: o empobrecimento narcísico da subjetividade. Kriterion, Belo Horizonte, n. 112, p. 332-344, dez. 2005.

FROMM, Erich. O dogma de Cristo e outros ensaios sobre religião, psicologia e cultura. 2. ed. Tradução de Waltensir Dutra. Rio de Janeiro: Zahar, 1965.

GOLDMANN, Lucien. A reificação das relações sociais. In: FORACCHI, Marialice M; MARTINS, José de Souza. Sociologia e sociedade: leituras de introdução à sociologia. Rio de Janeiro: Livros Técnicos e Científicos, 1980.

HABERMAS, Jürgen. Theodor W. Adorno - pré-história da subjetividade e auto-afirmação selvagem. In: FREITAG, Bárbara; ROUANET, Sergio Paulo. Habermas. 2. ed. São Paulo: Ática, 1990 (Coleção Grandes Cientistas Sociais, n 15).

HARVEY, David. Condição pós-moderna: uma pesquisa sobre as origens da mudança cultural. Tradução de Adail Ubirajara Sobral e Maria Stela Gonçalves. 4. ed. São Paulo: Loyola, 1994.

HELLER, Agnes. A sociologia como desfetichização da modernidade. Tradução de Maria Helena Souza Patto. Novos Estudos CEBRAP, n. 30, p. 204-214, jul. 1991.

HORKHEIMER, Max. Teoria crítica: uma documentação (tomo I). Tradução de Hilde Cohn. São Paulo: Perspectiva, 2008.

. Eclipse da razão. Tradução de Sebastião Uchoa Leite. 7. ed. São Paulo: Centauro, 2007.

HULLOT-KENTOR, Robert. Em que sentido exatamente a indústria cultural não mais existe. In: DURÃO, Fábio A.; ZUIN, Antonio; VAZ, Alexandre F. (Org.). A indústria cultural hoje. São Paulo: Boitempo, 2008.

LA BOÉTIE, Étienne de. Discurso da Servidão Voluntária. Tradução de Casemiro Linarth. São Paulo: Martin Claret, 2009 (Ediçáo Bilíngue Português/Francês).

KONDER, Leandro. A questão da ideologia. São Paulo: Companhia das Letras, 2002.

LUKÁCS, Georg. A reificação e a consciência do proletariado. In: . História e consciência de classe: estudos sobre a dialética marxista. Tradução de Rodnei Nascimento. São Paulo: Martins Fontes, 2003.

MAAR, Wolfgang Leo. Adorno, semiformação e educação. In: Educação e Sociedade. Campinas, vol. 24, n. 83, p. 459-476, ago. 2003. 
A perspectiva dialética em Adorno e a controvérsia com Habermas. In: Trans/ Form/Ação, São Paulo, 25, p. 87-105, 2002.

MANDEL, Ernest. A ideologia na fase do capitalismo tardio. In: O capitalismo tardio. Tradução de Carlos Eduardo Silveira Matos et al. 2. ed. Sáo Paulo: Nova Cultural, 1985.

MATOS, Olgária C. F. A Escola de Frankfurt: luzes e sombras do Iluminismo. 2. ed. São Paulo: Moderna, 2005.

MORIN, Edgar. La industria cultural. In: ADORNO, Theodor W; MORIN, Edgar. La industria cultural. Buenos Aires: Galerna, 1967.

PADILHA, Valquíria. A indústria cultural e a indústria do lazer: uma abordagem crítica da cultura e do lazer nas sociedades capitalistas globalizadas. In: MÜLLER, Ademir; DACOSTA, Lamartine Pereira (Org.). Lazer e desenvolvimento regional. Santa Cruz do Sul: EDUNISC, 2002.

ŽIŽEK, Slavoj. De história e consciência de classe à dialética do esclarecimento, e volta. Traduçáo de Bernardo Ricupero. Lua Nova, n. 59, p. 159-175, 2003.

ZUIN, Antonio Álvaro Soares. Morte em vídeo: Necrocam e a indústria cultural hoje. In: DURÃO, Fábio A.; ZUIN, Antonio; VAZ, Alexandre F. (Org.). A indústria cultural hoje. São Paulo: Boitempo, 2008.

. A vingança do fetiche: reflexóes sobre indústria cultural, educação pela dureza e vício. Educ. Soc., Campinas, vol. 27, n. 94, p. 71-90, jan./abr., 2006.

. Sobre a atualidade do conceito de indústria cultural. Cadernos Cedes, ano XXI, n. 54, p. 09-18, ago. 2001.

; PUCCI, Bruno; RAMOS DE OLIVEIRA, Newton. Adorno: o poder educativo do pensador crítico. 3. ed. Petrópolis: Vozes, 2001.

Recebido em: 29.08.2012

Aceito em: 10.11.2012 
COSTA, J. H. 